\title{
Effects of insulin-like growth factor I and interactions with transforming growth factor $\alpha$ and LH on proliferation of chicken granulosa cells and production of progesterone in culture
}

\author{
O. M. Onagbesan and M. J. Peddie \\ Department of Physiology and Pharmacology, Biomedical Sciences Building, University of Southampton, \\ Southampton SO9 3TU, UK
}

\begin{abstract}
The effects of insulin-like growth factor I (IGF-I), alone, and in combination with LH or transforming growth factor $\alpha$ (TGF- $\alpha$ ), on replication and progesterone production by cultured avian granulosa cells obtained from the three largest (F1-F3) follicles were studied. IGF-I and TGF- $\alpha$ stimulated proliferation of granulosa cells in a dose-dependent manner, and responsiveness decreased as the cells matured. IGF-I stimulated progesterone production from granulosa cells of all the follicles with no change in $\mathrm{ED}_{50}$ value during follicular maturation; however, the maximum response was from cells derived from F1 follicles. IGF-I plus LH had an additive effect on progesterone production by cells from all follicles. In contrast, TGF- $\alpha$ inhibited basal and LH- and IGF-I-stimulated progesterone production. These data show that IGF-I and TGF- $\alpha$ may interact with each other during granulosa cell maturation, such that efficacy of IGF-I increases, while that of TGF- $\alpha$ decreases before ovulation. Furthermore, both growth factors interact with $\mathrm{LH}$, either to enhance or inhibit progesterone production by granulosa cells. However, LH, IGF-I and TGF- $\alpha$ combine to stimulate proliferation of granulosa cells.
\end{abstract}

\section{Introduction}

The importance of gonadotrophins in regulating steroidogenesis in ovarian follicular granulosa cells of birds is well established. During follicular maturation, the granulosa tissue increases in size with a progressive increase in sensitivity to gonadotrophins (Asem and Hertelendy, 1985; Etches, 1990; Johnson, 1990). However, the role of growth factors as local paracrine and autocrine regulators in granulosa cells is less well characterized (Peddie et al., 1993). In contrast, there is substantial evidence of the role of insulin-like growth factor I (IGF-I) (Adashi et al., 1985a, 1992) and transforming-growth factor a (TGF- $\alpha$ ) (Adashi et al., 1987; May et al., 1990) as local modulators of ovarian function in mammals. IGF-I causes proliferation of granulosa cells and amplifies the effects of FSH on differentiation of granulosa cells and the synthesis of progesterone and oestrogen (Adashi $e t$ al., 1985b, 1988a; Hutchinson et al., 1988; Schams et al., 1988). In the thecal interstitial cells, LH/hCG-stimulated androgen production is enhanced by IGF-I (Cara and Rosenfeld, 1988; Hernandez et al., 1988). The IGF-I gene is expressed in the granulosa itself in rat and pig ovaries (Hsu and Hammond, 1987; Mondschein and Hammond, 1988; Oliver et al., 1989 and Hernandez et al., 1989), while IGF-I receptors have been localized in both granulosa and thecal cells (Davoren et al., 1986; Adashi et al., 1988b; Hernandez et al., 1990). In chickens, the IGF-I gene is localized within the granulosa and

Received I4 November 1994. thecal cells (Roberts et al., 1994). However, the effects of IGF-I on proliferation of granulosa cells and production of progesterone have not been extensively reported. Recent reports have shown that chicken granulosa and thecal cells contain IGF-I receptors and that IGF-I stimulates DNA synthesis in both cell types (Huybrechts et al., 1991; Roberts et al., 1994), whereas IGF-I stimulates production of progesterone by the granulosa cells in vitro (Peddie et al., 1993; Williams et al., 1994). Similarly, receptors for epidermal growth factor (EGF) and the ligands EGF and TGF- $\alpha$ were localized in the granulosa and theca (Onagbesan et al., 1994a) where they modulate cell proliferation and steroid production (Onagbesan et al., 1994b; Peddie et al., 1994). EGF/TGF- $\alpha$ are thought to be produced in thecal cell in mammals (Skinner et al., 1987; Lobb et al., 1989) and also possibly in birds (Peddie et al., 1994) and cause proliferation of granulosa cells and modulation of steroid synthesis.

The aim of the present study was to determine the effects of IGF-I on steroid production and replication of granulosa cells from the three largest follicles FI-F3. It is inevitable that increased numbers of granulosa cells during follicular growth will contribute to the total follicular production of progesterone, but modulation of the responses of individual cells to $\mathrm{LH}$ by potential paracrine factors may also contribute substantially to the overall progesterone production. We, therefore, also investigated the potential for modulation of $\mathrm{LH}$ responses by IGF-I and TGF- $\alpha$, and the possibility of interactions between IGF-I and TGF- $\alpha$ in regulating net progesterone production and of granulosa cell responses. 


\section{Materials and Methods}

\section{Animals}

Commercial ISA Brown hens, aged 25-35 weeks, were used for this study. Hens were kept in floor pens under a photoperiod of $14 \mathrm{~h}$ light: $10 \mathrm{~h}$ dark and fed on layers' diet and water ad libitum. Egg laying was recorded daily for each hen and hens laying 5-6 egg sequences were selected for experiments. Hens were killed by cervical dislocation $12-14 \mathrm{~h}$ before the next expected ovulation. The ovaries were removed and placed in warmed $\left(37^{\circ} \mathrm{C}\right)$ phenol-free Hanks' balanced salt solution (HBSS).

\section{Reagents}

Medium 199 (M199) with Earle's salts, phenol-free HBSS, antibiotic-antimycotic solution (PSA), BSA, L-glutamine, sodium bicarbonate, calcium- and magnesium-free HBSS, Hepes, trypsin-EDTA, Trypan blue, bisbenzamide, calf thymus DNA, transferrin, selenium and collagenase were obtained from Sigma Chemicals (Poole, Dorset). Fetal calf serum (FCS) was from Imperial Laboratories, (Andover, Hants), and recombinant human IGF-I and recombinant human TGF- $\alpha$ were purchased from Bachem Ltd (Saffron Walden, Essex). Ovine LH was a gift from S. Raiti (NIADDK, Baltimore, MD).

\section{Preparation and culture of granulosa cells}

The first (F1), second (F2) and third (F3) largest follicles in the ovary were removed and granulosa cells were prepared from each category of follicle separately as described by Peddie et al. (1994). Two or three birds were used for each experiment and granulosa cells from the same rank of follicles were pooled. Cell density was determined by measuring DNA in an aliquot using the method reported by Labarca and Paigen (1980) in which $1 \mu \mathrm{g}$ DNA corresponds to approximately $1 \times 10^{6}$ cells. Cell viabilities were assessed by the Trypan blue method and found to be greater than $95 \%$.

Cells were seeded at $0.2 \mu \mathrm{g}$ DNA per well in 24-well plastic plates and cultured in M199 supplemented with $2 \mathrm{mmol}$ glutamine $1^{-1}, 1 \%(\mathrm{v} / \mathrm{v})$ PSA and $5 \%(\mathrm{v} / \mathrm{v})$ charcoal-stripped FCS for $48 \mathrm{~h}$ in a humidified atmosphere of $5 \% \mathrm{CO}_{2}$ in air at $37^{\circ} \mathrm{C}$. The medium was discarded and cells washed with phenol-free HBSS and then cultured for a further $48 \mathrm{~h}$ in serum-free M199 supplemented with glutamine, sodium bicarbonate, $0.1 \%$ BSA, PSA, $6.25 \mu \mathrm{g}$ transferrin $\mathrm{ml}^{-1}$, $5 \mathrm{ng}$ selenium $\mathrm{ml}^{-1}$ and various concentrations $(0-100 \mathrm{ng}$ $\mathrm{ml}^{-1}$ ) of IGF-I with or without LH $\left(20 \mathrm{ng} \mathrm{ml}^{-1}\right)$. TGF- $\alpha$ $\left(0-100 \mathrm{ng} \mathrm{ml}^{-1}\right)$, with or without LH, was applied or the effects of combinations of IGF-I and TGF- $\alpha$ (with or without LH) were investigated, at doses defined in Figs 6 and 7. The total incubation volume was always $500 \mu \mathrm{l}$ per well. At the end of the second $48 \mathrm{~h}$ incubation period, culture media were collected and stored at $-20^{\circ} \mathrm{C}$ until assayed for progesterone. In another experiment, the cultures were washed twice with phenol-free HBSS and exposed for $3 \mathrm{~h}$ to a further $\mathrm{LH}$ challenge. For this, fresh M199 $(500 \mu \mathrm{l})$ containing $0.5 \%(w / v)$ BSA, with or without $20 \mathrm{ng} \mathrm{LH} \mathrm{ml}^{-1}$, was added and the cells incubated for $3 \mathrm{~h}$ at $37^{\circ} \mathrm{C}$ in a humidified atmosphere of $5 \%$ $\mathrm{CO}_{2}$ in air. Media were collected again and stored at $-20^{\circ} \mathrm{C}$ for progesterone assay.

\section{DNA content of wells}

Parallel plates were set up as described above to determine the DNA content of wells during and after the culture period. At the end of the second $48 \mathrm{~h}$ of culture, media were discarded and monolayer cultures washed with phenol-free HBSS. Cell viabilities were again checked before cells were disaggregated with $200 \mu \mathrm{l}$ trypsin-EDTA in $\mathrm{Ca}^{2+}$-free $2 \mathrm{~mol} \mathrm{NaCl}$-phosphate $1^{-1}$ buffer, followed by sonication. Viabilities were greater than $99 \%$ in all cell cultures. The DNA in aliquots of the lysate was determined by the method of Labarca and Paigen (1980) using calf thymus DNA as standard and bisbenzamide as the fluorogen.

\section{Hormone assay}

Progesterone was determined in the medium, without prior extraction, by radioimmunoassay as described by Brain $e t$ al. (1988). The minimum sensitivity of the assay was $0.01 \mathrm{pmol}$ per tube. The intra- and interassay coefficients of variation were $5.08 \%$ and $9.5 \%$, respectively.

\section{Statistical analyses}

Results are expressed as means \pm SEM of four experiments, each with four replicates. DNA content of wells is expressed as $\mu \mathrm{g}$ per well. All statistical analyses on progesterone data were transformed and expressed as pmol $\mu \mathrm{g}^{-1}$ DNA per well to account for changes in number of cells between follicles during the culture period. Differences between groups were compared by ANOVA followed by Duncan's multiple-range test where applicable. Two-way ANOVA was applied to test interactions between hormones where necessary and $P$ values $<0.05$ were considered significant.

\section{Results}

\section{Effects of IGF-I, TGF-a or LH on proliferation of granulosa cells}

IGF-I caused a marked increase in DNA content of culture wells (Fig. 1). The maximum effective dose of IGF-I was $12.5 \mathrm{ng} \mathrm{ml}^{-1}$. The $\mathrm{F} 3$ granulosa cell cultures showed the greatest response compared with the $\mathrm{F} 2$ and $\mathrm{F} 1$ cultures $(50 \%$ increase at maximum effective dose (ED) compared with 35\% for the F2 and $25 \%$ for the F1 granulosa). The calculated $\mathrm{ED}_{50}$ values for IGF-I on the proliferation of cells from the three follicles was $2.00 \mathrm{ng} \mathrm{ml}^{-1}$. Data on the effect of LH $(20 \mathrm{ng}$ $\left.\mathrm{ml}^{-1}\right)$, IGF-I (3.13 $\left.\mathrm{ng} \mathrm{ml}^{-1}\right)$ and TGF- $\alpha\left(0.078 \mathrm{ng} \mathrm{ml}^{-1}\right)$ alone, or in combination, on accumulated DNA per well are summarized (Fig. 2). At this dose, IGF-I had no significant effect, by itself, on replication by the F1 granulosa cells; TGF- $\alpha$ had a small, but significant, effect $(P<0.05)$, while a combination of TGF- $\alpha$ and IGF-I had no extra effect on the total DNA content 


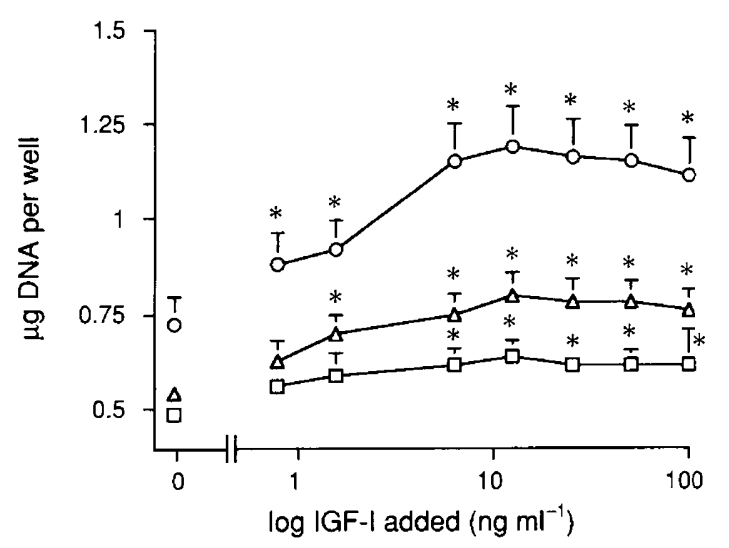

Fig. 1. Dose-dependent effects of insulin-like growth factor I (IGF-I) on accumulated DNA in chicken ovarian granulosa cells cultured from F1 $(\square), F 2(\triangle)$ or F3 $(0)$ follicles for $48 \mathrm{~h}$ in serum-free medium. Values are means \pm SEM of four experiments. ${ }^{*}$ Significantly different from respective control for each follicle size $(P<0.05)$.

of the wells. While neither LH nor IGF-I alone stimulated DNA accumulation in cells from the largest most mature follicle, $\mathrm{LH}$ and IGF-I together had a significant proliferative effect $(P<0.05)$. In contrast, the less mature cells were responsive to the mitogenic effects of IGF-I; $3.13 \mathrm{ng}$ IGF-I ml ${ }^{-1}$ caused a significant increase in DNA, as did $0.078 \mathrm{ng} \mathrm{TGF-} \alpha \mathrm{ml}^{-1}$ and together the growth factors showed increasing efficacy in less mature granulosa. LH had no significant effect by itself on granulosa from F2 and F3, but combined with IGF-I, it significantly potentiated the effect of IGF-I $(P<0.05)$. Thus, proliferative responses to both growth factors is greatest in the least mature cells, F3 > F2 > F1 $(P<0.05)$.

\section{Effect of IGF-I on progesterone production}

Data on progesterone production are expressed as pmol $\mu \mathrm{g}^{-1}$ DNA (Fig. 3), since the effects of IGF-I on proliferation were substantial and markedly influenced the interpretation of the raw data. The data show a dose-dependent stimulation of progesterone by IGF-I that reached a peak at a concentration of $25 \mathrm{ng}$ IGF-I ml ${ }^{-1}$. At this dose, granulosa cells cultured from FI follicles showed a significantly greater increase in basal progesterone production compared with cells from F2 and F3 cells $(P<0.001)$. The calculated $E_{50}$ values for progesterone production by the three follicles was $4.60 \mathrm{ng}$ IGF-I ml ${ }^{-1}$.

The response to a $3 \mathrm{~h} \mathrm{LH}$ challenge of cells previously cultured for $48 \mathrm{~h}$ with IGF-I in serum-free medium is shown (Fig. 4). Culturing granulosa cells with IGF-I, whilst enhancing basal progesterone production, also altered the ability of $\mathrm{LH}$ to subsequently cause an incremental increase in progesterone production. Basal and LH-stimulated progesterone production increased with increasing doses of IGF-I to a maximum dose of $12.5 \mathrm{ng} \mathrm{ml}^{-1}$. Previous exposure to IGF-I potentiated the response of the F1, F2 and F3 cells to $\mathrm{LH}$, and increased progesterone production by $200 \pm 26.4 \%, 43 \pm 6.20 \%$ and $5 \pm 1.02 \%$, respectively, at the maximum effective dose. However, the $\mathrm{ED}_{50}$ values for basal and LH-stimulated progesterone production under these short-term incubations were similar for all three follicle groups $\left(4.60 \mathrm{ng} \mathrm{ml}^{-1}\right)$.
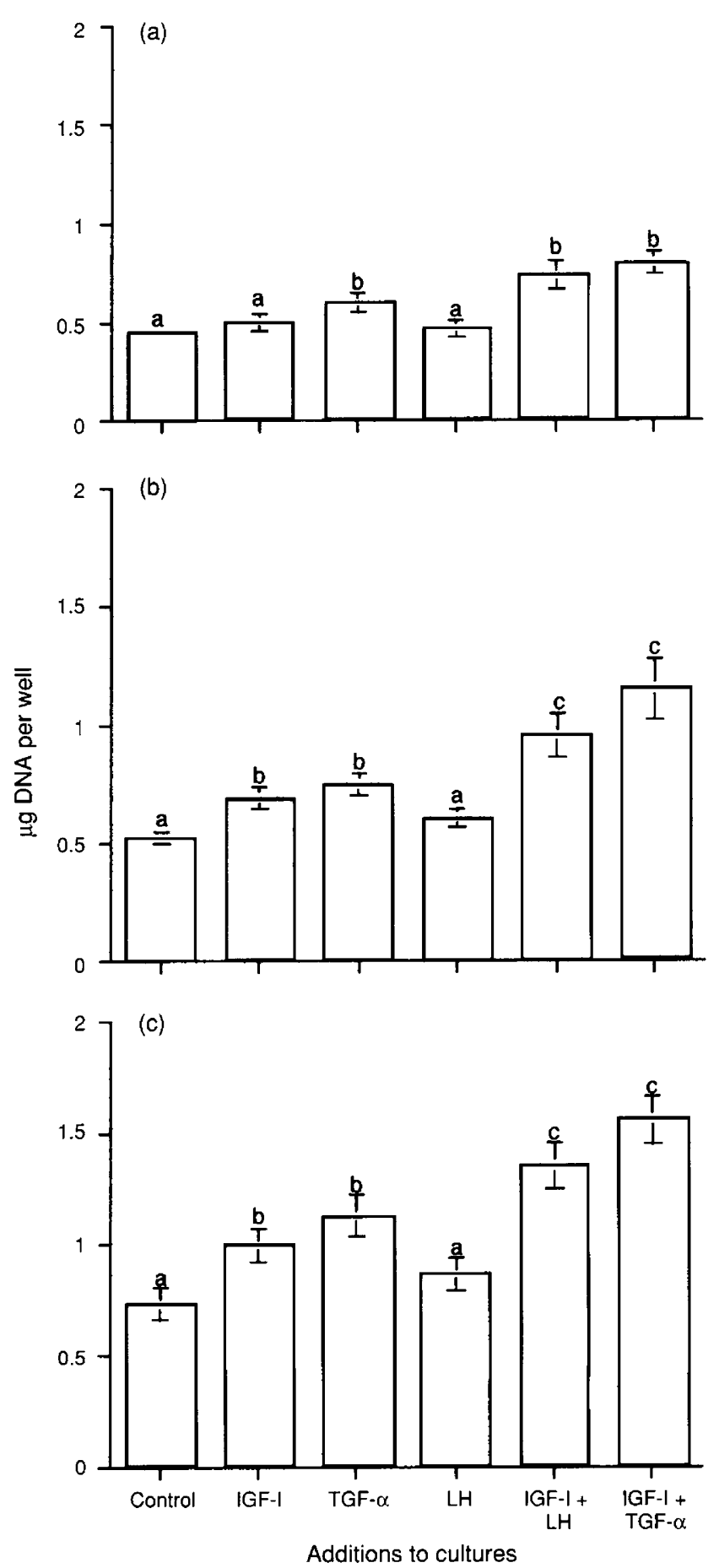

Fig. 2. Effects of insulin-like growth factor $I$ (IGF-I) $\left(3.13 \mathrm{ng} \mathrm{ml}^{-1}\right.$ ), $\mathrm{LH} \quad\left(20 \mathrm{ng} \mathrm{m}^{-1}\right.$ ) and transforming growth factor $\alpha$ (TGF- $\alpha$ ) $\left(0.078 \mathrm{ng} \mathrm{ml}^{-1}\right)$ alone or in combination, on accumulated DNA per well in chicken ovarian granulosa cells from (a) F1, (b) F2 and (c) F3 follicles cultured for $48 \mathrm{~h}$ in serum-free medium. Cultures were established in Medium 199 containing 5\% (v/v) serum for $48 \mathrm{~h}$, washed twice with HBSS and then cultured for a further $48 \mathrm{~h}$ in serum-free Medium 199 with IGF-I, TGF- $\alpha$, LH or combinations of hormone and growth factors added simultaneously. Values are means \pm SEM of four experiments. Different letters above columns indicate significant differences between treatments within each individual follicle category $(P<0.05)$. 


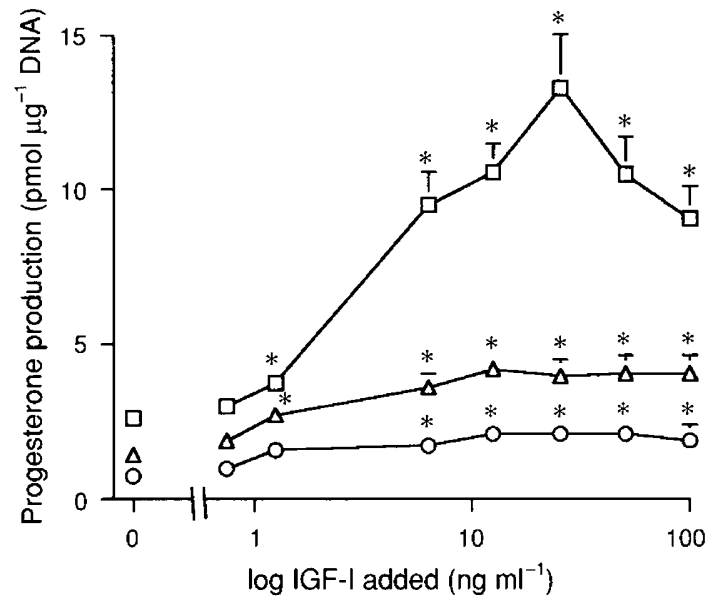

Fig. 3. Effect of insulin-like growth factor I (IGF-I) on progesterone accumulation in culture medium (pmol $\mu^{-1} \mathrm{DNA}$ ) by chicken granulosa cells from F1 (1.), F2 $(\Lambda)$ and F3 ( ) follicles cultured for $48 \mathrm{~h}$ in serum-free medium. Data are means \pm SEM of progesterone production during the second $48 \mathrm{~h}$ period of culture $(n=4)$. * Significantly different from respective control for each individual follicle size $(P<0.05)$.

The effect of culturing cells for a second $48 \mathrm{~h}$ period in serum-free medium with $20 \mathrm{ng} \mathrm{LH} \mathrm{ml}^{-1}$ in combination with various concentrations of IGF-I was also investigated. The results of progesterone accumulation in the medium is shown for F3 granulosa cells only (Fig. 5). Culturing cells in the presence of IGF-I enhanced progesterone accumulation in the medium as before, with an $\mathrm{ED}_{50}$ value of $4.60 \mathrm{ng} \mathrm{ml}^{-1}$. The addition of $\mathrm{LH}$ alone caused $95 \pm 10.8 \%$ increase in progesterone accumulation and this basal production of progesterone was significantly potentiated by IGF-I $(P<0.05)$. Again, the effect of IGF-I was dependent on the dose and follicle size.

\section{Interactions of IGF-I with LH and TGF-a on progesterone production}

The dose-dependent effects of TGF- $\alpha$ on progesterone accumulation in the medium during the second $48 \mathrm{~h}$ period of culture in serum-free medium for F3 granulosa cells are shown (Fig. 6). TGF- $\alpha$ inhibited progesterone production by up to $75 \%$ at the maximum effective dose of $10.1 \mathrm{ng} \mathrm{ml}^{-1}$. The effects of culturing cells in the presence of $20 \mathrm{ng} \mathrm{LH} \mathrm{ml}{ }^{-1}$, $3.13 \mathrm{ng}$ IGF-1 ml ${ }^{-1}$, and $0.078 \mathrm{ng}$ TGF- $\alpha \mathrm{ml}^{-1}$ and combi-

Fig. 4. Progesterone production (pmol $\mu \mathrm{g} \mathrm{DNA}^{-1}$ ), after a $3 \mathrm{~h}$ LH challenge, by chicken granulosa cells previously cultured for $48 \mathrm{~h}$ with increasing amounts of insulin-like growth factor I (IGF-I) $\left(0-100 \mathrm{ng} \mathrm{ml}^{-1}\right)$ in serum-free medium. Granulosa cells from (a) F1, (b) F2 and (c) F3 follicles were established and then cultured with IGF-I for $48 \mathrm{~h}$; the culture media were discarded and cells were washed twice with HBSS and then incubated with ( $\mathbb{Z})$ or without $(\square) \mathrm{LH}$ $\left(20 \mathrm{ng} \mathrm{m}^{-1}\right)$ for a further $3 \mathrm{~h}$. Data are means $\pm \operatorname{SEM}(n=4)$ of progesterone production during the $3 \mathrm{~h}$ incubation. *Significantly different from cultures without LH treatment at each dose of IGF-I $(P<0.05)$. nations of hormone and growth factors on progesterone accumulation in the medium during the second $48 \mathrm{~h}$ period of culture in serum-free medium are summarized (Fig. 7). LH or IGF-I alone stimulated progesterone production in all three follicle categories and IGF-I and LH together had a significantly greater $(P<0.05)$ effect than either one alone; the combined
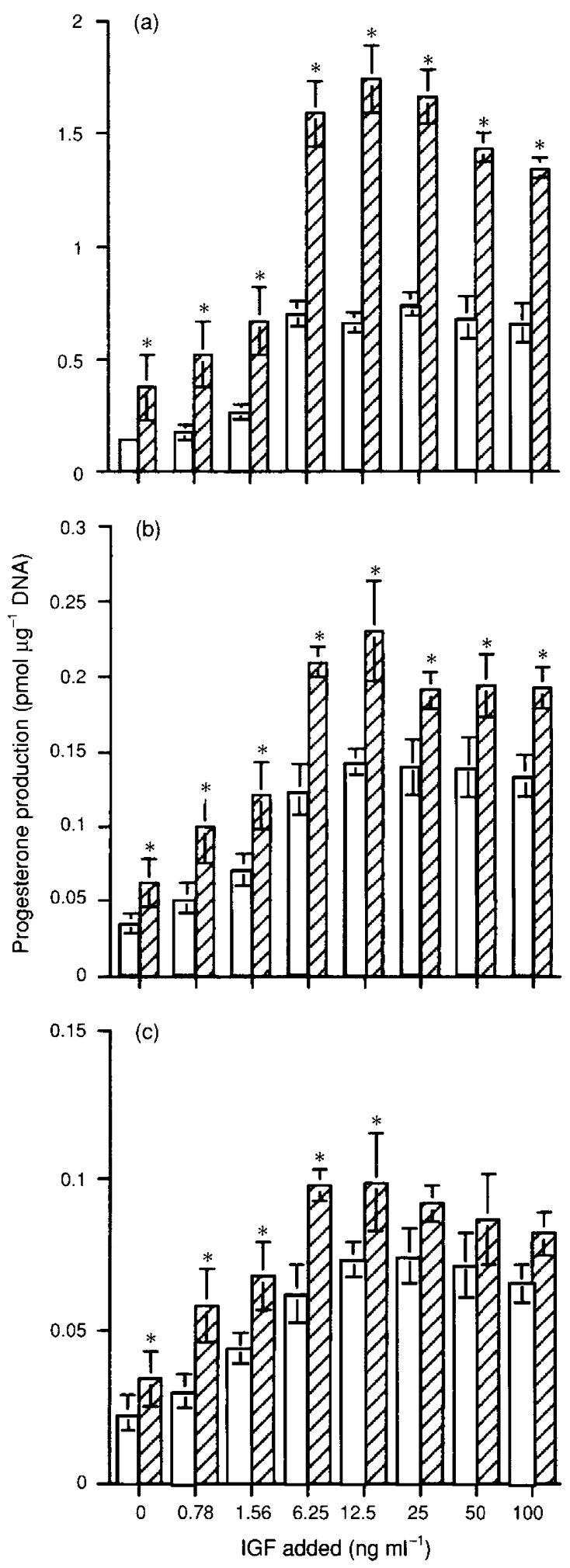


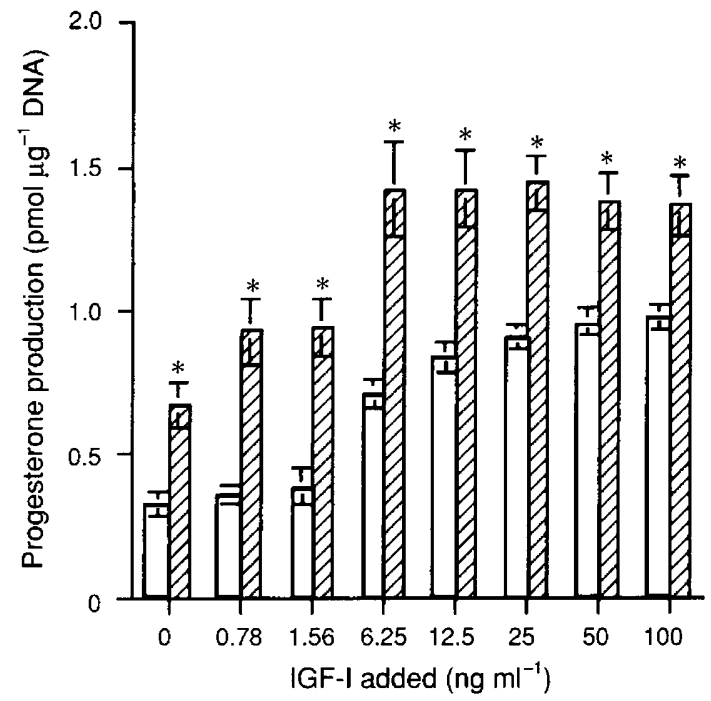

Fig. 5. Effects of insulin-like growth factor I (IGF-I) and LH on progesterone production by chicken F3 granulosa cells cultured for $48 \mathrm{~h}$ with combinations of IGF-I $\left(0-100 \mathrm{ng} \mathrm{ml}^{-1}\right)$ and LH $\left(20 \mathrm{ng} \mathrm{ml}^{-1}\right)$ in serum-free medium. Granulosa cells from F3 follicles were established, washed and then cultured for a further $48 \mathrm{~h}$ in serum-free medium with IGF-I only ( $\square$ ) or with IGF-I and LH ( $\square)$ added to the culture simultaneously. Data are means \pm SEM of accumulated progesterone during the $48 \mathrm{~h}$ of culture $(n=4)$. *Significantly different cultures with IGF-I only present $(P<0.05)$.

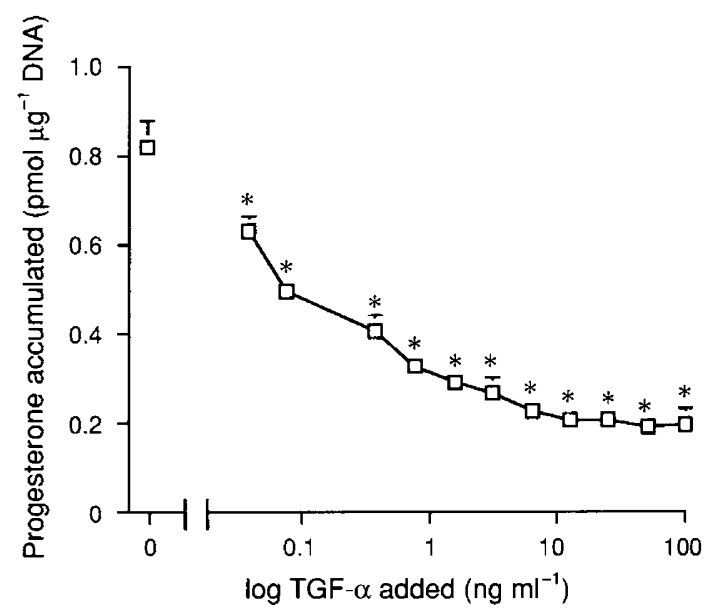

Fig. 6. Dose-dependent inhibitory effect of transforming growth factor $\alpha$ (TGF- $\alpha$ ) on progesterone production by chicken F3 granulosa cells cultured for $48 \mathrm{~h}$ in serum-free medium. Granulosa cultures were established as previously described, washed twice and then cultured for a further $48 \mathrm{~h}$ in serum-free Medium 199 containing different concentrations of TGF- $\alpha\left(0-100 \mathrm{ng} \mathrm{ml}^{-1}\right)$. Data are means \pm SEM of progesterone accumulated in the medium during the $48 \mathrm{~h}$ culture period. *Significantly different from the control $(P<0.05)$.

effects were additive in F2 and F3 but summated in F1. TGF- $\alpha$ inhibited basal progesterone production in the $\mathrm{F} 2$ and $\mathrm{F} 3$ follicles, and the effect of either LH or IGF-I alone or in combination in all three follicle categories. The inhibitory effect of $0.078 \mathrm{ng} \mathrm{TGF}-\alpha \mathrm{ml}^{-1}$ on the combined effect of LH and IGF-I appeared to be greatest in the F3 group, with a reduction of about $50 \pm 8.20 \%$; whereas in F1 group, this dose
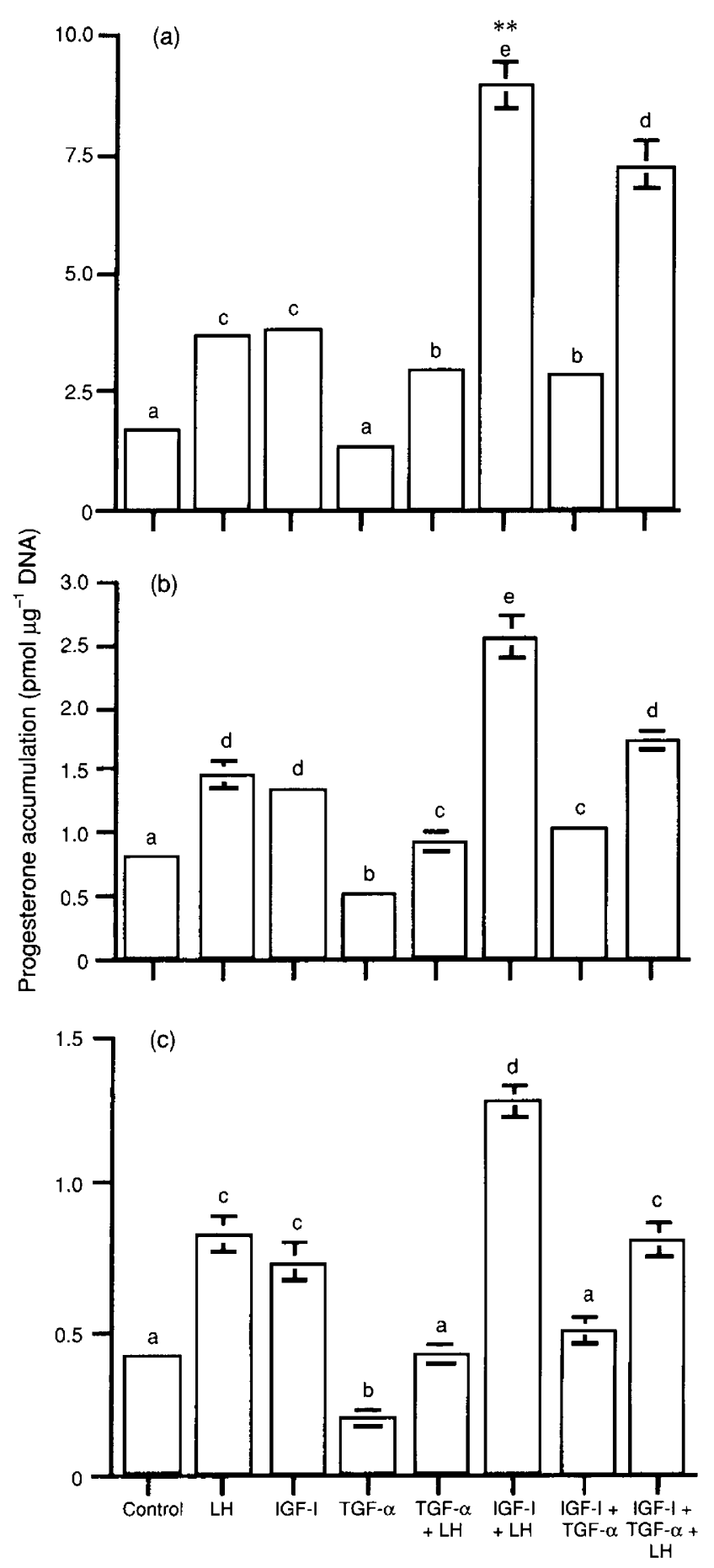

Additions to cultures

Fig. 7. Effects of insulin-like growth factor I (IGF-l) $\left(3.13 \mathrm{ng} \mathrm{m}^{-1}\right)$, LH $\left(20 \mathrm{ng} \mathrm{ml}^{-1}\right.$ ) and transforming growth factor $\alpha$ (TGF- $\alpha$ ) ( $0.078 \mathrm{ng} \mathrm{ml}^{-1}$ ) on progesterone accumulation in the culture medium by chicken (a) F1, (b) F2 and (c) F3 granulosa cells cultured for $48 \mathrm{~h}$ in serum-free medium. Cultures were established, washed twice in HBSS, and then cultured for a further $48 \mathrm{~h}$ in serum-free Medium 199 containing the growth factors or $\mathrm{LH}$ alone, or in combination, added simultaneously. Data are means $\pm \mathrm{SEM}$ of progesterone accumulated during the $48 \mathrm{~h}$ culture period. Different letters above columns indicate significant differences $(P<0.05)$ between treatments within each follicle category. ${ }^{* *} P<0.01$ synergistic effect between IGF-I and LH. 
caused only a $20 \pm 2.25 \%$ reduction in LH/IGF-l-stimulated progesterone production.

\section{Discussion}

The effects of $\mathrm{LH}$ on avian granulosa cells are well documented (Johnson, 1990), although the effects of LH or FSH on the proliferation of granulosa cells are less well researched (Yoshimura and Tamura, 1988; Roberts et al., 1994). However, the differences in sensitivity of the follicles to these hormones during maturation suggest that additional intra-ovarian modulatory systems exist. Current opinion, from mammalian work, suggests that putative intra-ovarian regulators, including the IGFs and EGF-like peptide family, are engaged in subtle modulation of the growth and function of ovarian cells. We reported the effects of EGF on the proliferation of and progesterone production from cultured granulosa cells of chickens (Peddie et al., 1994). However, in contrast to mammals, the effects of the IGFs in birds remain to be clarified, although mRNA encoding IGF-I is expressed in the granulosa and theca of chicken ovaries (Roberts et al., 1994). Roberts et al. (1994) also showed that IGF-I stimulated $\left[{ }^{3} \mathrm{H}\right]$ thymidine incorporation into both the granulosa and thecal cells in culture but no data on the effects on progesterone production were given. We recently reported that IGF-I stimulated progesterone production by cultured granulosa cells, but at that time the influence of proliferation on net progesterone production was not incorporated (Williams et al., 1994). In contrast, the results of the present study show that while IGF-I stimulates both proliferation and progesterone production by cultured avian granulosa cells, these effects are independent of each other, and that although the $\mathrm{ED}_{50}$ value of IGF-I did not alter during follicular maturation, the total amount of progesterone secreted per cell increased markedly as the follicle matured. However, the effects of IGF-I on proliferation were greatest in the F3 cells, with no changes in $\mathrm{ED}_{50}$ value and maximum response. It has been suggested that IGF-I-enhanced progesterone production from the granulosa and theca of mammals is due to stimulation of $\mathrm{P} 450 \mathrm{scc}$ and the $3 \beta$-hydroxysteroid dehydrogenase expression (Adashi et al., 1986; Veldhuis et al., 1986; Magoffin and Weistman, 1993). Since the activities of these enzymes also increase during follicular maturation in chicken cells (Davidson et al., 1979; Armstrong, 1982), IGF-I may exert its effect on progesterone production via these enzymes. This is consistent with the lack of effect on $\mathrm{ED}_{50}$ value but greater maximal progesterone production with IGF-I. However, the interactions between IGF-I and LH which further enhanced progesterone production may be more complex since in rats gonadotrophins were found to enhance IGF-I binding to granulosa cells and IGF-I can stimulate an increase in the expression of LH/FSH receptors (Adashi et al., 1986).

It has been suggested that EGF-like peptides may have a role in the avian ovary (Pulley and Marrone, 1986; Yoshimura and Tamura, 1988). EGF inhibits progesterone production by chicken granulosa cells (Pulley and Marrone, 1986; Peddie et al., 1994), while stimulating cell proliferation (Yoshimura and Tamura, 1988; Peddie et al., 1994). Here, we have demonstrated that TGF- $\alpha$, a peptide with considerable similarity to EGF, also inhibits basal and LH-stimulated progesterone production by cultured chicken granulosa cells Tilly and Johnson (1990) reported an inhibition of progesterone production by freshly dispersed granulosa cells; however, they did not compare changes in responsiveness during follicular maturation and they did not examine effects on proliferation. Our data also show that TGF- $\alpha$ can inhibit IGF-I-stimulated progesterone production and that the sensitivity of the cultured cells to TGF- $\alpha$ greatly exceeds that to IGF-I. TGF- $\alpha$ also stimulates proliferation of granulosa cells with an additive effect when in combination with IGF-I. Thus TGF- $\alpha$ and EGF have similar actions in granulosa cells, although the $\mathrm{ED}_{50}$ value for TGF- $\alpha\left(0.20 \mathrm{ng} \mathrm{ml}^{-1}\right)$ is 100 times lower than that of EGF (20 ng ml ${ }^{-1}$ ) (Peddie et al. 1994). This difference probably reflects the difference in binding affinity of TGF- $\alpha\left(K_{\mathrm{d}}=0.9 \times 10^{-9} \mathrm{~mol} \mathrm{l}^{-1}\right)$ and EGF $\left(K_{\mathrm{d}}=2.6 \times 10^{-7} \mathrm{~mol} \mathrm{l}^{-1}\right.$ ) for the avian EGF-receptor (Lax et al., 1989).

The study reported here clearly demonstrates that any one growth factor acting alone is unlikely to be responsible for regulating any one granulosa cell function. We have previously shown that the sensitivity of the granulosa to EGF diminishes as the follicle matures, thus allowing for increased production of progesterone as the follicle matures (Peddie et al., 1994). The study reported here shows that increasing efficacy of IGF-I during follicular maturation also leads to increased progesterone production. It would seem, therefore, that a balance between these two growth factors may regulate responses to $\mathrm{LH}$ and account for the increasing responsiveness of the cells to $\mathrm{LH}$ before the $\mathrm{LH}$ surge. However, the two growth factors also interact with LH to stimulate cell proliferation. Thus, successive LH surges before ovulation contribute to the growth and maturation of the smaller follicles. Hence, during follicular maturation, increasing numbers of granulosa cells and their increasing sensitivity to $\mathrm{LH}$ account for the increased production of progesterone from the preovulatory follicles. It remains to be determined whether thecal production of TGF- $\alpha$, or synthesis of IGF-I and its binding proteins, are also modulated during follicular maturation, but alterations in intra-ovarian production or activity of these growth factors are additional factors which will contribute to the regulation of ovarian progesterone production, by granulosa cells.

\section{References}

Adashi EY, Resnick CE, D'Ercole AJ, Svoboda ME and Van Wyk JJ (1985a) Insulin-like growth factors as intra-ovarian regulators of cell growth and function Endocrine Reviews 6 400-420

Adashi EY, Resnick CE, Svoboda ME and Van Wyk JJ (1985b) Somatomedin-C synergizes with follicle-stimulating hormone in the acquisition of progesterone biosynthetic capacity by cultured rat granulosa cells Endocrinology $1162369-2375$

Adashi EY, Resnick CE, Svoboda ME and Van Wyk JJ (1986) Follicle-stimulating hormone enhances somatomedin- $\mathrm{C}$ binding to cultured rat granulosa ceils:evidence for a cAMP dependence Journal of Biological Chemistry 261 3923-3926

Adashi EY, Resnick CE and Twardzik DR (1987) Transforming growth factor 0 attenuates the acquisition of aromatase activity by cultured rat granulosa cells Journal of Cellular Biochemistry 33 1-13

Adashi EY, Resnick CE, Hernandez ER, May JV, Knetch M, Svoboda ME and Van Wyk J (1988a) Insulin-like growth factor-I as an amplifier of FSH action: 
studies on the mechanism(s) and site(s) of action in cultured rat granulosa cells Endocrinology 122 1583-1591

Adashi EY, Resnick CE, Hernandez ER, Svoboda ME and Van Wyk JJ (1988b) Characterization and regulation of a specific cell membrane receptor for somatomedin-C/insulin-like growth factor I in cultured rat granulosa cells Endocrinology 112 194-201

Adashi EY, Resnick CE, Hurwitz A, Ricciarellie E, Hernandez ER, Roberts CT Leroith D and Rosenfeld R (1992) The intra-ovarian IGF system Growih Regulation 2 10-15

Armstrong DG (1982) 33-Hydroxy- $\Delta^{5}$-steroid dehydrogenase activity in the rapidly growing ovarian follicles of the domestic fowl (Gallus domesticus) Journal of Endocrinology 93 415-421

Asem EK and Hertelendy $\mathbf{F}$ (1985) Influence of follicular maturation on $\mathrm{LH}_{\text {, }}$ CAMP, forskolin and cholesterol-stimulated progesterone production in hen granulosa cells Biology of Reproduction 32 257-268

Brain P, Onagbesan OM, Peddie MJ and Taylor TG (1988) Changes in plasma concentrations of reproductive steroids in female Japanese quail (Coturnix coturnix japonica) raised under long or short photoperiods General and Comparative Endocrinology 69 174-180

Cara JF and Rosenfield RL (1988) Insulin-like growth factor-I and insulin potentiate luteinizing hormone-induced androgen synthesis by rat ovarian theca-interstitial cells Endocrinology 123 733-739

Davidson MF, Gilbert AB and Wells JW (1979) Activity of the ovarian $3 \beta$-hydroxysteroid dehydrogenase in the domestic fowl (Gallus domesticus) with respect to age Journal of Reproduction and Fertility 57 61-64

Davoren JB, Kasson BG, Li CH and Hsueh AJW (1986) Specific insulin-like growth factor-I and -II binding sites on rat granulosa cell: relation to IGF action Endocrinology 119 2155-2162

Etches RJ (1990) The ovulatory cycle of the hen Current Reviews of Poultry Biology 2 293-318

Hernandez ER, Resnick CE, Svoboda ME, Van Wyk JJ, Payne DW and Adashi EY (1988) Somatomedin-C/insulin-like growth factor-I as an enhancer of androgen biosynthesis by cultured rat ovarian cells Endocrinology $\mathbf{1 2 2}$ $1603-1612$

Hernandez ER, Roberts CT, Jr and Adashi EY (1989) Rat ovarian insulin-like growth factor I (IGF-I) gene expression is granulosa cell-selective $5^{t}$-untranslated mRNA variant representation and hormonal regulation Endocrinology 125 572-574

Hernandez ER, Roberts CT, Hurwitz A, LeRoith D and Adashi EY (1990) Rat ovarian insulin-like growth factor-II gene expression in theca-interstitial cell exclusive: hormonal regulation and receptor distribution Endocrinology 127 3249-3252

Hsu CJ and Hammond JM (1987) Gonadotropins and estradiol stimulate immunoreactive insulin-like growth factor-I production by porcine granulosa cells in vitro Endocrinology 120 198-207

Hutchinson LA, Findlay JK and Herington AC (1988) Growth hormone and insulin-like growth factor-I accelerate PMSG-induced differentiation of granulosa cells Molecular and Cellular Endocrinology 55 61-69

Huybrechts LM, Decuypere E and Kühn E (1991) Granulosa cells of preovulatory follicles of domestic fowl contain an insulin-like growth factor (IGF) receptor Medical Sciences Research 19 699-700

Johnson AL (1990) Steroidogenesis and actions of steroids in the hen ovary Critical Reviews of Poultry Biology 2 319-346

Labarca $C$ and Paigen $K$ (1980) A simple, rapid and sensitive DNA assay procedure Analytical Biochemistry 102 344-352

Lax I, Bellot F, Howk R, Ullich A, Givol D and Schlessinger J (1989) Functional analysis of the ligand-binding site of EGF-receptor utilizing chimeric chicken/human receptor molecules EMBO Journal $8421-427$
Lobb DK, Kobrin MS, Kudlow JE and Dorrington J (1989) Transforming-growth factor $\alpha$ in the adult bovine ovary: identification in the growing ovarian follicles Biology of Reproduction 40 1087-1093

Magoffin DA and Weitsmann SR (1993) Insulin-like growth factor-I stimulates the expression of $3 \beta$-dehydrogenase messenger ribonucleic acid in ovarian theca-interstitial cells Biology of Reproduction 48 1166-1173

May JV, Frost JP and Bridge AJ (1990) Regulation of granulosa cell proliferation: facilitative roles of platelet-derived growth factor and low density lipoprotein Endocrinology 126 2896-2905

Mondschein JS and Hammond JM (1988) Growth factors regulate immunoreactive insulin-like growth factor production by cultured granulosa cells Endocrinology 123 463-468

Oliver JE, Aitman TJ, Powel JF, Wilson CA and Clayton RN (1989) Insulin-like growth factor-I expression in the rat ovary is confined to granulosa cells of developing follicles Endocrinology 124267 1-2679

Onagbesan OM, Gullick W, Woolveridge I and Peddie MJ (1994a) Immunohistochemical localization of epidermal growth factor receptors, epidermal-growth-factor-like and transforming-growth-factor- $\alpha$-like peptides in chicken ovarian follicles Journal of Reproduction and Fertility 102 147-153

Onagbesan OM, Peddie MJ and Williams J (1994b) Regulation of cell proliferation and estrogen synthesis by ovine LH, IGF-I and EGF in thecainterstitial cells of the domestic hen cultured in defined media General and Comparative Endocrinology 94 261-272

Peddie MJ, Onagbesan OM and Woolveridge I (1993) The role of epidermalgrowth factor and other factors in the paracrine and autocrine control of ovarian follicular development in the domestic hen. In Avian Endocrinology pp 321-330 Ed. PJ Sharp. Journal of Endocrinology Ltd, Bristol

Peddie MJ, Onagbesan OM and Williams J (1994) Chicken granulosa cell proliferation and progesterone production in culture: effects of EGF and theca secretions General and Comparative Endocrinology 94 341-356

Pulley DD and Marrone BL (1986) Inhibitory action of epidermal-growth factor on progesterone biosynthesis in hen granulosa cells during short-term culture: two sites of action Endocrinology 118 2284-2291

Roberts RD, Sharp PJ, Burt DW and Goddard C (1994) Insulin-like growth factor-I in the ovary of the laying hen; gene expression and biological actions on granulosa and theca cells General and Comparative Endocrinology $93 \quad 327-336$

Schams D, Koll R and Li CH (1988) Insulin-like growth factor-I stimulates oxytocin and progesterone production by bovine granulosa cells in culture Journal of Endocrinology $11697-100$

Skinner MK, Lobb D and Dorrington JH (1987) Ovarian theca/interstitial cells produce an epidermal-growth-factor-like substance Endocrinology 121 $1892-1899$

Tilly JL and Johnson AL (1990) Modulation of hen granulosa cell steroidogenesis and plasminogen activator activity by transforming-growth factoralpha Growth Factors 3 247-255

Veldhuis JD, Rodgers RJ, Dee A and Simpson ER (1986) The insulin-like growth factor, somatomedin $\mathrm{C}$, induces the synthesis of cholesterol side-chain cleavage cytochrome P450 and andrenodoxin in ovarian cells Journal of Biological Chemistry 261 2499-2502

Williams J, Onagbesan OM and Peddie MJ (1994) Actions of growth factors on the ovary of the laying hen (Gallus domesticus) Contraception Fertilite Sexualite 22 577-586

Yoshimura $\mathrm{Y}$ and Tamura T (1988) Effects of gonadotrophins, steroid hormones and epidermal growth factor on the in vitro proliferation of chicken granulosa cells Poultry Science 67 814-818 